\title{
LIBERALISMO, JUSTIÇA E DEMOCRACIA: RUI BARBOSA E A CRÍTICA À PRIMEIRA REPÚBLICA BRASILEIRA (1910-1921)*
}

\author{
Wendel Antunes Cintra
}

Professor Adjunto do Departamento de Ciência Política da Faculdade de Filosofia e Ciências

Humanas da UFBA. Salvador, BA. Brasil. E-mail: <cintra.wendel@gmail.com>

http://dx.doi.org/10.1590/ 0102-6445201-231/99

Rui Barbosa (1849-1923) desenvolveu seu pensamento político em meio à participação na vida pública. Sua longa trajetória como político, jurista e publicista - que remonta à luta abolicionista durante o Segundo Império ainda na década de 1880 e se estende pela Primeira República quando foi duas vezes candidato à presidência (1910 e 1919) -, em vez de apresentar um desenvolvimento linear e unívoco, é permeada de rupturas, adaptações e revisões. Assim, não parece apropriado tomar sua vasta produção intelectual como um bloco monolítico, como doutrina fechada que teria se desenvolvido de modo coerente do início ao fim da carreira. Defini-lo como "liberal" pouco ajuda a compreender a dinâmica de seu pensamento e ação, e isso não apenas porque o conceito de liberalismo é demasiado generalista e polissêmico, mas porque Rui mobilizava o arsenal teórico liberal, adaptando-o aos contextos políticos em que ele intervinha, enfatizando determinados pontos em detrimento de

Agradeço a Marcelo Jasmin, Christian Lynch e Maria Fernanda Lombardi, que sugeriram desenvolver o tema Rui Barbosa contido em minha tese de doutorado Qual democracia: o governo do povo no pensamento político brasileiro (1914-1945) (Cintra, 2013). 
outros e, inclusive, em certas ocasiões, incorporando temas e abordagens estranhas ao próprio repertório do liberalismo clássico. Nesse sentido, compreender o liberalismo de Rui implica situá-lo no contexto político-intelectual em que ele atuava, reconhecer seus interlocutores - adversários e aliados -, bem como atentar para seus objetivos imediatos.

Este artigo examina a obra tardia de Rui Barbosa, aqui datada a partir de sua ruptura definitiva com o senador Pinheiro Machado - então a principal liderança parlamentar do situacionismo republicano -, obra esta que se caracterizou pelo desenvolvimento de uma crítica cada vez mais incisiva contra as oligarquias republicanas que duraria até o fim de sua carreira política.

Questiona-se: como Rui, que fora um dos principais artífices da República, avaliava o "desvio de rota" daquele regime que, não obstante ter sido fundado em "bons princípios" federalistas e liberais, acabara corrompendo-se em um sistema polí202 tico autoritário, em que sequer havia respeito pelos direitos civis mais elementares? Como o jurista baiano, talvez em diálogo crítico consigo mesmo, pensava o abismo que separava a letra da Constituição das práticas políticas ordinárias? Por que as promessas não haviam se cumprido? E que tipo de saída Rui vislumbrava para o país, já que o problema na década de 1910 já não era combater o modelo saquarema, centralizador, mas se opor a um tipo de política autoritária praticada por oligarquias regionais com o apoio do Executivo federal sob o manto sagrado de uma Constituição liberal-federalista.

Argumento que, entre 1910 e 1921, o tema do federalismo e do liberalismo econômico passaram a ocupar um lugar cada vez mais marginal nas intervenções de Rui. Tendo como objetivo deslegitimar as práticas da política oficial republicana, a política dos governadores e a centralização de poder no Executivo federal, Rui se viu obrigado a renovar seu próprio liberalismo, acolhendo fórmulas do reformismo social cristão e da social-democracia. Do ponto de 
vista programático, o jurista desenvolveu um conceito normativo de "democracia jurídica", que serviu de referência para sua crítica ao establishment republicano e que se compunha fundamentalmente de dois eixos: (1) organização e autonomia da sociedade civil e (2) primazia do Poder Judiciário como summa potestas do regime republicano.

\section{Uma "democracia esfarrapada": ilegalidade e farsa representativa na Primeira República}

O ponto de partida do diagnóstico de Rui na década de 1910 é de que teria havido um processo de corrupção e degeneração do regime republicano brasileiro, cujo resultado foi a usurpação do poder da nação pelas oligarquias. Nessa narrativa, a utopia de construção de uma democracia liberal, que inspirara os fundadores da República, aparecia em contraste com uma realidade em que vigorava o arbítrio e a força. Para Rui, o "espírito" da Carta de 1891 era refutado pela própria experiência republicana, e seus princípios não encontravam efetividade diante de uma situação política que oscilava, segundo ele, entre a ditadura e a anarquia.

Para elaborar sua crítica da situação política brasileira na década de 1910, Rui Barbosa recorria ao repertório doutrinário do liberalismo clássico. Como se sabe, um tema central dessa tradição diz respeito às tendências despóticas consideradas intrínsecas ao poder político. Desde o século XVIII, pensadores como Montesquieu, Madison, Hamilton e, já no início do século XIX, Benjamin Constant, viam no poder ilimitado o principal traço dos regimes despóticos. Guardadas as devidas diferenças e nuances das obras de cada um desses autores, a crítica à "soberania ilimitada" compõe o núcleo dessa cultura política. Em contraposição às doutrinas políticas baseadas em conceitos de soberania concentrada - como aquelas desenvolvidas por Jean Bodin, Thomas Hobbes ou Jean-Jacques Rousseau -, a boa ordem política no registro liberal dependeria de um conjunto de mecanismos 
institucionais celebrados na fórmula freios e contrapesos, cuja função seria precisamente limitar o poder, impedindo que ele se convertesse em tirania. Em tal abordagem, a própria distinção entre bons e maus regimes, entre liberdade e despotismo, resultava menos da origem do poder em si (se monárquica ou popular) que do modo pelo qual ele era exercido. O despotismo nasceria precisamente da ausência ou ineficácia de instâncias que atuassem como contrapoderes. Daí a importância de uma engenharia institucional capaz de impedir, ou ao menos atenuar, a expansão ilimitada do poder ${ }^{1}$.

Em meados da década de 1910, no Brasil, Rui Barbosa servia-se desses postulados da doutrina liberal para a crítica do situacionismo republicano. Segundo ele, um dos principais traços do desvirtuamento da República brasileira dizia respeito ao fato de que aqui as classes dirigentes encontravam débeis limites institucionais para o exercício do poder 204 político. Exemplo disso era o poder quase ilimitado do Executivo federal e seus aliados nos estados. Rui denunciava que o princípio da divisão de poderes, tal como previsto na Constituição de 1891, vigorava de modo muito precário no país e, com frequência, os governos extravasavam suas competências institucionais, cooptando o Congresso e o Judiciário, limitando as liberdades civis, perseguindo oposicionistas ou intervindo violentamente para derrubar os governos estaduais considerados adversários. Se o Poder Executivo não encontrava contenção nos outros poderes da República, o que tínhamos na prática, dizia Rui, era uma "democracia esfarrapada” (Barbosa, 1989 [1914], p. 224).

\footnotetext{
1 A formulação clássica desse problema está em Montesquieu ao analisar a Constituição inglesa no livro Espirito das leis. Segundo o autor, a principal característica dessa Constituição era precisamente a separação e o controle mútuo entre os poderes, o que impossibilitava que qualquer um deles fosse exercido sem a recíproca limitação dos outros (Montesquieu, 1996 [1748], pp. 166-79). Para uma análise da dicotomia entre as concepções de soberania concentrada e de "Constituição mista” no pensamento político moderno, ver Araujo (2013) e Skinner (1996).
} 
Uma das consequências do poder ilimitado do Executivo era a constante violação de direitos fundamentais no país. Em muitos de seus escritos dessa época, o jurista baiano empenhava-se em denunciar as violações das liberdades civis garantidas pela Constituição. A crítica ao abuso de decretos de Estado de sítio, que suspendiam direitos de livre expressão e de reunião, era emblemática de sua posição. Para Rui, o instituto legal do Estado de sítio, regido pelos artigos 34, 48 e 80 da Constituição de 1891, embora previsto para casos de "agressão por forças estrangeiras" ou "grave comoção intestina", ou seja, para situações extraordinárias, acabou se tornando uma espécie de modus operandi do governo durante a Primeira República². O abuso nas decretações do Estado de sítio - que já havia sido objeto de crítica de Rui Barbosa nos primeiros anos da República, durante o governo de Floriano (Lynch, 2012, p. 159) ${ }^{3}-\mathrm{o}$ levou, em março de 1914, a impetrar vários pedidos de habeas

2 Christian Lynch (2012) argumenta que tanto a figura jurídica do Estado de sítio como a interpretação prevalecente acerca das situações autorizadoras de sua decretação foram inspirados na Constituição argentina de 1853 e no uso que se fazia do instituto naquele país. No Brasil da Primeira República, argumenta o autor, o Estado de sítio tornou-se recorrente para a solução das crises políticas ordinárias: "Caído em desuso sob o Império havia quase meio século, a República fez do Estado de sítio instrumento ordinário de governo: foram onze até a queda do regime (1891, 1892, 1893, 1897, 1904, 1910, 1914, 1917/1918, 1922/1923, 1924/1926, 1930" (Lynch, 2012, p. 158).

3 Ainda de acordo com Lynch, a interpretação liberal da aplicação dos dispositivos legais que regulamentavam o Estado de sítio, cujo principal expoente durante a década de 1890 havia sido o próprio Rui Barbosa, fracassou diante das interpretações do situacionismo, seja em sua versão "jacobina" durante o governo Floriano Peixoto, "puritana", na linha de Quintino Bocaiúva, ou na vitoriosa versão oligárquica, então defendida por Campos Sales (Lynch, 2012, pp. 160-64). A esse respeito, Lynch (p. 159) observa que "contrapondo-se à interpretação conservadora e maximizadora conferida àquele instituto [do Estado de sítio] pelo situacionismo, o liberal Rui Barbosa forjou uma exegese alternativa, minimalista, ancorado na qual impetrou habeas corpus em favor dos presos junto ao Supremo Tribunal Federal. [...] Uma de suas maiores preocupações, havia sido justamente a de fortalecer o judiciário, conferindo-lhe um extenso papel na defesa das instituições por meio da jurisdição constitucional". Como veremos, as intervenções de Rui Barbosa na década de 1910 seguiriam essa mesma linha argumentativa, isto é, tinham como finalidade atribuir ao STF a competência para, em última instância, validar os atos do Executivo, inclusive sobre a aplicação e vigência do Estado de sítio. 
corpus no STF com o objetivo de garantir a imunidade parlamentar dos oposicionistas e a liberdade de imprensa, após mais uma utilização daqueles dispositivos para conter suposta "conspiração" durante governo Hermes ${ }^{4}$.

Com efeito, a tibieza das instituições, incapazes de estabelecer um controle mútuo entre os poderes da República, e a precariedade da supremacia da Constituição, frequentemente violada pelos governantes em proveito próprio, eram vistas por Rui como características que atuavam no sentido de corromper o princípio do governo do povo. Ao impedir ou obstaculizar o exercício de liberdades civis básicas, a classe governante brasileira colocava em xeque a própria democracia, minando o pluralismo e deturpando a formação da opinião pública.

O problema, contudo, não se limitava à esfera institucional e aos desmandos do Poder Executivo. A inequívoca tendência da República brasileira para se converter em uma 206 "ditadura" ou uma "autocracia”, análogas ao czarismo russo ou o império germânico (Barbosa, 1986 [1919], pp. 20-22), também podia ser observada na baixíssima autonomia da sociedade civil e sua capacidade de auto-organização. A esse respeito, Rui acreditava que a deturpação ou inversão da representação política no Brasil devia-se em grande medida à asfixia da esfera pública. Parlamento e imprensa, segundo ele "órgãos vitais do governo representativo", haviam sido cooptados pelas oligarquias e não mais se constituíam em espaços livres para a vocalização dos anseios da nação.

\footnotetext{
4 De acordo com Américo Jacobina Lacombe (1973), o decreto de 25 de abril de 1914 foi motivado por suspeitas de que o antigo Ministro da Guerra, Mena Barreto, e o governador de Pernambuco, Dantas Barreto, conspiravam no Clube Militar contra o governo. O decreto serviu como pretexto para a prisão de jornalistas e a censura da imprensa, e durou até outubro daquele ano. Os habeas corpus impetrados por Rui naquela ocasião visavam beneficiar além dele próprio, os parlamentares Irineu Machado e Pedro Moacir, libertar jornalistas e suspender a censura aos jornais oposicionistas (Lacombe, 1973, pp. ix-xi). A esse respeito, ver também Nery (1955, pp. 122-25).
} 
No que tange à autonomia na formação da opinião pública diante dos governos instituídos, o jurista baiano avaliava que do Império à República teria havido inclusive um retrocesso. Sob o reinado de Dom Pedro II, avaliava, não sem algum saudosismo, o Brasil tivera uma imprensa e um parlamento muito mais autônomos e comprometidos com as grandes causas da nação que nos tristes dias da República.

O regímen constitucional, na Monarquia, tinha, entre nós, dois largos pulmões, o Parlamento e a imprensa, por onde a vida nacional se oxigenava livremente. [...] A tribuna legislativa era a gloriosa arena, onde as ideias e as virtudes se batiam pelas aspirações da honra e do civismo. No jornalismo ainda não havia mercados abertos para as secretarias, os esconderijos policiais e as verbas escusas do orçamento (Barbosa, 1986 [1919], p. 16).

Na República, a situação era inversa. Os antigos "pulmões" do governo representativo, que oxigenavam o corpo político e influenciavam o governo no Segundo Império, encontravam-se agora asfixiados pela ação nociva das oligarquias. O novo regime, dizia, convertera-se, na prática, em uma "caricatura da soberania nacional" (Barbosa, 1986 [1919], p. 17). A imprensa, de modo geral, deixava de cumprir seu papel cívico, pois já não expressava as correntes da opinião pública nacional, tampouco tinha autonomia para se opor aos governantes e vigiar seus atos. Ao contrário, os jornais se tornaram paulatinamente um dos instrumentos de manutenção do status quo republicano, meros veículos de transmissão dos interesses das oligarquias e manipulação do eleitorado. Diante dessa situação, Rui denunciava com veemência a submissão dos jornais aos políticos, os quais, com uso indevido de verbas públicas, cooptavam os meios de comunicação do país em benefício próprio. 
Hoje, Tesouro Federal, tesouros estaduais, tesouros municipais, tudo deita para esse vazadoiro [os órgãos de imprensa]. Salvam-se, destarte, jornais encravilhados, erguem-se novos, outros se criam somente para o enxoval do batizado. No termômetro do zelo sobe ou desce a temperatura, segundo a altura do metal na cuba do oiro. Com a caixa aberta, os mais desacreditados governos gozam, todas as manhas, de fanfarra à porta. Com os postigos da pagadoria cerrados, não haveria governo que servisse (Barbosa, 1986 [1919], p. 19).

Um ano depois de pronunciar essas palavras, Rui voltava a tratar da relação entre a formação da opinião pública e a democracia em outra conferência cujo título é por si só bastante eloquente: A imprensa e o dever da verdade (1990 [1920]). A ação dos governos voltada a manipular os meios de comunicação - como ocorria no Brasil por meio de "subvenções" 208 aos jornais - era, para Rui, própria dos regimes absolutistas e autocráticos. "Todos os regimens, dizia, que descaem para o absolutismo vão entrando logo a contrair amizades suspeitas entre os jornais" (Barbosa, 1990 [1920], p. 23). E para dar subsídio ao seu argumento, ele citava o trabalho de 1887, de Henri Wuttke, Le fond des reptiles: le journalisme allemand et la formation de l'opinion publique, que tratava dos mecanismos utilizados pelo governo alemão para cooptar a imprensa sob o governo Bismarck. Práticas como suborno e desvio de verbas públicas tornaram-se comuns na Alemanha àquela época e constituíram uma "fábrica de opinião pública" capaz de angariar o apoio do povo com a deturpação da verdade em favor do governo (Barbosa, 1990 [1920], p. 23). Rui (pp. 26-30) denunciava que, desde Campos Sales, o Brasil seguia o mesmo caminho, com os sucessivos governos republicanos agindo para manipular a imprensa, de modo a torná-la subserviente aos seus interesses. Em suas palavras, predominava no país a "mercantilidade jornalística, alimen- 
tada pelos manejos oficiais" (p. 32), uma situação em que os governos "assalariavam os jornais" (p. 33) e faziam deles "casas de prostituição intelectual” (p. 44).

Essas denúncias de Rui contra os seus adversários revelam um ponto fundamental em sua concepção de governo representativo: com a intervenção do governo na imprensa, o poder político se autonomizava em relação à nação e à sociedade civil. Com a corrupção dos órgãos responsáveis pela formação da opinião pública, as decisões governamentais passavam a ser tomadas sem a devida publicidade, sem discussão ou esclarecimento prévios e sem controles efetivos por parte da sociedade civil. Daí, Rui argumentar que a República havia se convertido em um "governo conventicular”, cujas principais decisões eram tomadas às escuras, sem qualquer consulta à nação. No Brasil, dizia,

[...] se inutilizaram os órgãos vitais do governo representativo, as válvulas do seu aparelho respiratório e o centro do seu sistema vascular. Acabaram, a um tempo, com a tribuna e a imprensa. Encerraram as câmaras legislativas numa atmosfera de servilidade e mercantilismo. Os negócios invadiram o sagrado recinto dos procuradores da soberania nacional e os postos de vigia das sentinelas do povo à obra dos seus servidores. [...] Comercializou-se a pena dos jornalistas e o voto dos legisladores. O poder achou-se de todo em todo sem fiscalização, nem freios, manejando a publicidade como encobrideira dos seus abusos, centralizando num mecanismo geral de clandestinidade a legislatura, o jornalismo, a telegrafia, e convertendo, assim o governo constitucional em governo conventicular (Barbosa, 1986 [1919], p. 20).

Para além das metáforas e certos exageros retóricos, tão ao gosto de Rui e próprios de uma campanha presidencial, o que importa destacar nessas citações é que havia um diagnóstico de deturpação no processo de formação da vontade 
da nação. Antecipando questões que ganhariam relevo na teoria democrática na segunda metade do século XX, em particular em expoentes da teoria deliberativa, Rui preocupava-se com a questão da colonização da esfera pública pelo poder estatal-administrativo, que deturpava a vontade da maioria expressa pelo voto e, como corolário, tornava tal critério (majoritário-eleitoral) inadequado para a aferição do interesse público. Em outras palavras, ao atentar contra a autonomia dos órgãos de imprensa, os governos republicanos corrompiam a própria formação da vontade popular e, no limite, a própria democracia.

\section{A nação contra o número}

Depreende-se desse diagnóstico da situação política brasileira na década de 1910 que as desventuras da democracia no país não resultavam da baixa cultura cívica do povo, mas, antes, derivavam da ação nociva das oligarquias governantes

210 que, como vimos, exerciam um poder autocrático e suprimiam os órgãos de expressão da sociedade civil.

A esse respeito, é oportuno salientar que Rui em sua obra tardia passou a dar cada vez mais ênfase às potencialidades cívicas do povo brasileiro, que ele contrastava com as tendências particularistas e autointeressadas das oligarquias. Na conferência A questão social e política no Brasil, pronunciada durante a campanha presidencial de 1919, no Teatro Lírico no Rio de Janeiro, ele expressava mesmo um sentimento de demofilia quando se empenhava em refutar a imagem do personagem Jeca Tatu - tal como descrita no famoso ensaio Urupês, de Monteiro Lobato ${ }^{5}$.

5 Publicado originalmente como ensaio no jornal O Estado de S. Paulo em dezembro de 1914, Urupês foi coligido em livro em 1918. Seu sucesso editorial tornou o personagem Jeca Tatu bastante popular desde então. Em prosa algo sardônica, Lobato nos apresentava o caboclo brasileiro como um tipo preguiçoso, inerte, conformista, analfabeto e apegado às crenças místicas. Em suas palavras, tratava-se de uma raça que "existe a vegetar de cócoras, incapaz de evolução, impenetrável ao progresso. Feia e sorna, nada a põe de pé” (Lobato, 2007, p. 169). 
O Jeca Tatu era uma representação cética e pessimista do homem do campo, formulada como um ataque direto ao que Lobato considerava ser a "idealização" romântica do século XIX. Porém, para o então candidato à presidência da República Rui Barbosa, o personagem de Lobato era emblemático menos de uma suposta essência do homem rural que dos preconceitos que as elites dirigentes nutriam em relação a ele. "O gênio do artista [dizia Rui sobre Lobato], refletindo alguma cousa do seu meio, nos pincelou, consciente, ou inconscientemente, a síntese da concepção, que têm, da nossa nacionalidade, os homens que a exploram" (Barbosa, 1998, [1919] p. 9).

O desprezo das classes dirigentes brasileiras por seu próprio povo, argumentava Rui, obviamente não havia se iniciado com Monteiro Lobato, mas tinha raízes longínquas. Desde os jesuítas, passando pelos comerciantes de escravos, aos grandes fazendeiros da atualidade, a história do país havia sido uma sucessão de opressão e descaso em relação ao povo. Ao tratar da "questão social", o candidato oposicionista à presidência lamentava que a República, "reacionária desde o seu começo", não dera continuidade ao processo de emancipação dos trabalhadores brasileiros após o fim da escravidão. Sem qualquer assistência governamental ou política pública para integrar os libertos, o trabalhador rural brasileiro vivia em uma situação de penúria. Nessa narrativa, a inviabilização da democracia no Brasil não resultava de características socioculturais essencialistas, supostamente encarnadas na imagem do Jeca Tatu, mas sim de suas elites, que impediam a expressão autêntica da nacionalidade e de suas potencialidades (Barbosa, 1989 [1919], p. 12).

Em outros escritos, Rui repercutia esse sentimento de demofilia, que contrastava com perspectivas que descreviam um povo inepto à prática da cidadania política. Mesmo após sua derrota eleitoral para Epitácio Pessoa, ele mantinha o 
mesmo tom otimista quanto às potencialidades cívicas do povo brasileiro. Recordando da experiência da Campanha Civilista, ele dizia que,

[...] bem longe de ser essa massa de papa-moscas, vilões e egoístas, indiferentes a tudo, como estão habituados a pintálo os que não conhecem, ou o caluniam, não há povo mais sensível aos nobres estímulos do civismo, do direito ou da honra que o povo brasileiro, em aparecendo quem o procure, quem o alumie, que o convença, que lhe dirija a palavra com verdade, e na pureza das suas intenções lhe tenha dado motivos para acreditar (Barbosa, 1956b [1919], p. 200).

Apesar desse otimismo quanto ao civismo do homem comum, Rui fazia questão de distinguir a vontade da nação da expressão numérica do voto. Ele descrevia sua própria candidatura - derrotada duas vezes nas urnas (1910 e 1919) - como

212 verdadeira expressão da vontade nacional. Para fundamentar seu argumento do divórcio entre a nação e a maioria, Rui enfatizava o fato de ter obtido as votações mais expressivas nas regiões em que, segundo ele, havia se desenvolvido uma sociedade civil moderna, organizada e dinâmica, isto é, onde as oligarquias não tinham como exercer um controle direto, tal como faziam com o eleitorado rural e do interior do país ${ }^{6}$. Rui utilizava termos como "fábrica eleitoral”, "açambarcadores eleitorais", "empreiteiros de presidências" para designar a inversão representativa que vigia no país, sobretudo no interior, em que os governos construíam as maiorias eleitorais ao invés de elas escolherem seus governos ${ }^{7}$.

6 De fato, como nota seu biógrafo, nas eleições de 1919, Rui venceu em todas as capitais, exceto Manaus e Paraíba (atual João Pessoa) (Viana Filho, 1941, pp. 280-81).

7 Nesse aspecto, as teses de Rui estão muito próximas daquelas desenvolvidas mais tarde por autores como Victor Nunes Leal (1975 [1949]), que identificam no atraso socioeconômico e na dependência do eleitor rural as principais causas da inversão do sistema representativo brasileiro. 
Havia, nessa narrativa ruiana, dois brasis: um em que vicejava o mandonismo, a farsa representativa, as fraudes; e outro, urbano, culto e progressista, como expressa o autor neste trecho do "Manifesto..." em sua campanha presidencial de 1919:

[...] por todo o Brasil, como presídios da sua vontade [das oligarquias], acostumada a não ser vencida, as seções rurais, mais ou menos distantes da ebulição civilizadora, ou esses outros núcleos urbanos, condenados, com nota usual de burgos podres, à estagnação crônica pelas circunstâncias especiais de sua história e destino. Aí se acastela, com o mandonismo de aldeia, a velha e sórdida fraude, amestrada na manifestação das atas eleitorais, que tem convertido as eleições entre nós "numa guerra de papéis [...] e constituem a moeda falsa, com que os governos brasileiros eliminam da circulação a verdade eleitoral, abafando os votos da gente livre e culta, que ainda não desacorçoou de acudir às urnas (Barbosa, 1956b [1919], p. 207).

Nesse sentido, Rui (pp. 209-12) tecia elogios à "cultura urbana de São Paulo”, que, contrariando os desígnios do governo estadual, lhe concedera uma expressiva votação, e, ao comentar o processo eleitoral que lhe dera vitória em Salvador, lamentava que "dado o sistema eleitoral que impera hoje em dia, essas manifestações da energia popular só se lograriam traduzir em votos, com certa seriedade, nos centros urbanos policiados e cultos" (p. 206).

É importante destacar que, não obstante Rui denunciasse a fraude eleitoral como um dos componentes da farsa representativa, tal prática não era em seu diagnóstico nem a única, nem a mais importante no impedimento da realização da "verdade representativa". Para ele, a vontade nacional não era, nem podia ser simples expressão 
do número, porque havia um problema na própria formação da vontade, a qual, por definição, era anterior ao processo eleitoral. Daí o argumento recorrente em seus textos de que era imprescindível que as eleições - como mecanismo para a expressão da vontade da nação - fossem precedidas por um processo de depuração capaz de fazer convergir a força numérica do voto com o interesse da nação. E isso, na avaliação de Rui, estava longe de ser uma realidade no Brasil. Com efeito, ainda que a crítica da fraude eleitoral estivesse presente em seu discurso, ela não ocupava o centro de seu programa político. Para que fosse legítima a vontade das urnas, era necessário que o número fosse resultado de um processo complexo de formação da opinião nacional e, sobretudo, que esse processo estivesse livre da influência direta dos governantes e da máquina administrativa-estatal ${ }^{8}$. $\mathrm{O}$ conceito normativo de democracia em Rui, como veremos, tentava lidar precisa214 mente como esses problemas identificados na formação da vontade da nação.

\section{0 programa normativo de Rui Barbosa: soberania da nação e democracia jurídica}

Como já assinalado, a militância política de Rui Barbosa entre 1910 e 1921 tinha como Leitmotiv a regeneração da República brasileira, que, segundo ele, tivera seus princípios corrompidos pela ação nociva das oligarquias e pela corrupção das instituições. Regenerar, reorganizar ou restituir a res publica, naquele contexto, implicava a criação de mecanismos que permitissem à nação retomar a soberania, ilegitimamente usurpada pelas oligarquias. Isso posto, a democracia

\footnotetext{
8 Nesse ponto, Rui diverge de Assis Brasil (1927, 1931), que tinha na organização do voto o centro de sua plataforma política. A realização da "democracia" no país, para Rui, dependia antes da formação da opinião pública e de uma sociedade civil autônomas. Sobre o tema de representação política na obra de Assis Brasil e no debate da Primeira República, ver Hollanda (2009).
} 
concebida por Rui dependia da realização de dois princípios fundamentais: de um lado, a organização da nação, entendida basicamente como fortalecimento das associações da sociedade civil e engajamento cívico com a finalidade de atenuar a manipulação do eleitorado rural desorganizado; de outro, a efetiva supremacia da Constituição que, na prática, se realizaria pela atribuição ao Superior Tribunal Federal da função de summa potestas do regime republicano, convertendo-o em árbitro dos conflitos federativos e garantidor dos direitos civis dos cidadãos.

\section{Decifrando a nação}

Rui, como dito, avaliava que a aritmética do voto era um mecanismo insuficiente para a realização da democracia. Assim, a questão fundamental passava a ser como transcender as limitações do princípio majoritário-eletivo e revelar a "verdadeira" vontade da nação para além das maiorias ocasionais manipuladas pelo situacionismo. A saída apontada por ele ia na direção do fortalecimento das associações da sociedade civil e sindicatos patronais e de trabalhadores, vistos como uma espécie de nação qualitativa, vocacionada para a realização do interesse público. Nesse registro, caberia às "classes conservadoras", isto é, "as forças do trabalho, da produção, da riqueza e da honra", que estavam "esparsas até agora" organizarem-se em associações e correrem "à conquista legal das urnas". O associativismo civil seria uma estratégia, portanto, para vencer a "mentira eleitoral" que então vigorava no país (Barbosa, 1986 [1919], p. 16). A verdadeira nação não correspondia às "maiorias silenciosas" mobilizadas eleitoralmente, mas "a lavoura, o comércio, a instrução, a magistratura e as forças armadas", que expressavam uma "ordem orgânica, integrada pelo trabalho e pelo associativismo” (p. 8). Essa nação qualitativa, para Rui, baseava sua legitimidade no direito, na razão e no trabalho, e não na força numérica. 
Daí seu apelo para que tais classes se organizassem para vocalizar suas demandas e influenciar o poder.

Tal abordagem, como se nota, distancia-se do individualismo liberal ortodoxo e se assemelha em grande medida àquela desenvolvida na mesma época por Alberto Torres (1933 [1914], 1978 [1914]) e, mais tarde, por Oliveira Viana (1927). Ainda que haja importantes diferenças no que tange à formatação institucional da democracia na obra dos três autores, há uma preocupação comum em fortalecer a sociedade civil organizada e criar meios institucionais para representá-la. Essa organização era uma condição sine qua non para superar o predomínio do facciosismo da política oligárquica e realizar o interesse nacional. Nesse sentido, há um registro comum no qual a nação, em vez de ser descrita como agregado de indivíduos atomizados ou agrupamento dos interesses dos estados, é pensada como uma conjunção harmônica de subcorpos coletivos - asso-

216 ciações, corporações, sindicatos -, cujos interesses convergiriam na formação de uma vontade nacional unificada. $\mathrm{O}$ paralelo, porém, se limita ao diagnóstico do problema da organização da sociedade civil, pois Rui sequer cogitava a institucionalização de modalidades de representação corporativa. O político baiano, ao contrário de Torres e de Oliveira Vianna, acreditava que a mobilização das classes produtivas e das associações civis deveria se dar com a conquista do sufrágio e não a partir da criação de novas modalidades de representação corporativa.

\section{Democracia social}

Um dos pontos importantes no programa de Rui, quanto ao fortalecimento da sociedade civil, tinha a ver com o tema da "questão social". Na Campanha de 1919, o candidato à presidência se empenhou em atualizar a doutrina liberal clássica - de matriz individualista e antiestatista - às reivindicações sociais do proletariado, o que implicava o reconhe- 
cimento de um novo gênero de direitos, não mais aplicados aos indivíduos, mas à coletividade ${ }^{9}$.

Nesse registro, contra a "inflexibilidade individualista" das Constituições, Rui defendia uma adequação das novas Cartas "ao sopro de socialização" que "agita[va] o mundo" (Barbosa, 1998 [1919], pp. 66-67). Para ele, o processo de socialização exigia um novo olhar sobre a sociedade, que já não podia ser concebida contemporaneamente como um "mero agregado, uma justaposição de unidades individuais acasteladas cada qual no seu direito intratável”, mas, ao contrário, devia ser apreendida como "uma entidade naturalmente orgânica, em que a esfera do indivíduo tem por limites inevitáveis, de todos os lados, a coletividade" (p. 25). Para superar o anacronismo de uma Constituição baseada em princípios individualistas, seria necessário acolher novas noções jurídicas, agora fundamentadas em conceitos sociais e coletivos. O trabalho, dizia Rui, não podia ser considerado uma mercadoria a ser livremente

9 Trata-se de uma radical mudança de Rui no seu entendimento da questão social. Com efeito, ele passou de um liberalismo econômico individualista e dogmático para um liberalismo social, incorporando demandas dos trabalhadores da cidade e do campo (Moraes Filho, 1981). O antiestatismo do jovem Rui levou-o a apoiar durante o Governo Provisório vários projetos de lei no sentido de evitar qualquer tipo de regulação jurídica do mercado de trabalho. Em artigo publicado no jornal A Imprensa, seu ponto de vista acerca do tema é exposto com clareza solar: "Somos por princípio avessos a toda regulamentação de serviços de qualquer ordem. Há nela sempre uma diminuição da liberdade individual, um constrangimento incompatível com o trabalho verdadeiramente livre. As tendências do Estado para regulamentar as relações entre o patrão e o empregado, o amo e o serviçal, não nos são simpáticas" (Barbosa, 1898 apud Moraes Filho, 1981, p. xiii). Mesmo na Campanha Civilista, já em 1910, o tema estava praticamente ausente das intervenções de Rui - talvez porque a crítica que ele fazia à República pudesse ser dirigida contra ele próprio. Não cabe, no âmbito deste artigo, discutir as razões que o levaram à mudança de posição, mas algumas hipóteses podem ser aventadas, como a busca estratégica de apoio eleitoral entre as classes operárias urbana e rural para compensar seu isolamento político, ou ainda a própria tendência mundial no sentido do reformismo social, sobretudo após a Primeira Guerra e a Revolução Russa. O que importa notar é que, para elaborar sua crítica à experiência da Primeira República, Rui teve de se valer de um vocabulário estranho ao do individualismo liberal ortodoxo, que até pouco tempo antes lhe havia servido como única referência. 
contratada seguindo a lei da oferta e da procura, sem que houvesse qualquer intervenção estatal nessa relação. A solução da questão social dependia de um conjunto de leis que visassem à proteção do trabalhador contra a exploração desmesurada do capital. A regulação jurídica do mercado de trabalho, argumentava ele, visava precisamente garantir os direitos da coletividade, impedido o predomínio da lei do mais forte. O exemplo da limitação da jornada de trabalho a oito horas diárias é ilustrativo desse entendimento:

A limitação das horas de trabalho interessa às condições fisiológicas de conservação de classes inteiras, cuja higiene, robustez e vida entendem com a preservação geral da coletividade, com a defesa nacional, com a existência da nacionalidade brasileira. Não será lícito, pois, que o deixemos ao domínio da contratualidade, que redundaria 218 na preponderância incontrastável da parte mais forte sobre a mais desvalida (Barbosa, 1998 [1919], p. 52).

Contra o campo situacionista, liderado por Epitácio Pessoa e Borges de Medeiros, que defendiam a autonomia dos estados e sua competência para legislar sobre o trabalho sem interferência da União, Rui se colocava a favor de uma reforma constitucional que atribuísse ao Congresso Nacional competência para legislar em matéria trabalhista. Sintonizado com as tendências intervencionistas na legislação social em curso na Europa e também nos Estados Unidos - cujos exemplos mais emblemáticos eram o Tratado de Versalhes e a Constituição de Weimar, ambos de 1919 -, Rui defendia que fossem objetos de Lei federal não apenas a limitação da jornada de trabalho referida, mas também medidas como política habitacional para as classes operárias, seguro obrigatório em caso de acidentes de trabalho, regulação do trabalho dos menores, regulação do trabalho 
noturno, igual remuneração para igual trabalho, leis de proteção específica para a trabalhadora gestante, além de medidas para garantir a higiene e salubridade nas fábricas.

É importante destacar que esse reformismo social ruiano estava inserido em uma agenda política que visava fortalecer os setores urbanos da sociedade civil, naquele caso específico, o operariado. O reformismo social seria um dos momentos da formação de uma nação integrada e autônoma perante o governo. A defesa dos direitos sociais e a melhoria das condições materiais de vida dos operários, desse ponto de vista, não tinha como finalidade fomentar o antagonismo e o conflito entre as classes sociais, mas antes buscava harmonizá-las. Rui acreditava que essas medidas dariam forma a uma "democracia social" no Brasil, uma democracia que não estivesse assolada pela divisão entre partidos ou classes, mas integrada em seus diversos segmentos organizados ${ }^{10}$.

\section{Autonomia da opinião pública}

O fortalecimento da sociedade civil organizada dependia também da emancipação da opinião pública em relação aos governantes. Se o governo do povo pelo povo se caracterizava pela difusão do poder por toda a sociedade, não estando mais restrito à pessoa pública do príncipe absoluto, o direito à informação e à verdade passava a ser um dos pilares do regime. "É, sobretudo, mediante a publicidade que os povos respiram", dizia Rui Barbosa (1990 [1920], p. 21). Daí que nas "democracias de hoje", em que "as pessoas de cetro são todas as que têm o mando nos negócios comuns,

\footnotetext{
${ }^{10}$ Nesse sentido, Rui fazia questão de distinguir essa "democracia social" do bolchevismo russo e também da doutrina da social-democracia alemã (Barbosa, 1998 [1919], pp. 25-26; 64-65). Diversamente, ele tomava como paradigma a doutrina do cardeal belga Joseph-Desiré Mercier (1851-1926), um expoente do reformismo social cristão, cuja pregação repercutia princípios da Encíclica Rerum Novarum (1891), do papa Leão XIII.
} 
desde o chefe do Estado até os eleitores, desde os legisladores até os juízes, desde os tribunos até os jornalistas", todos deveriam submeter-se ao princípio da publicidade (p. 49).

Para Rui, a opinião pública em uma democracia deveria exercer duas funções principais. A primeira delas era, em alguma medida, análoga à exercida pelo Poder Judiciário, isto é, atuar como uma espécie de poder negativo para limitar o arbítrio dos governantes. Apesar de não ser propriamente um poder institucionalizado com competências e atribuições específicas, a opinião pública exerceria uma vigilância cotidiana sobre os governantes, corrigindo potenciais equívocos ou abusos de poder. Em outras palavras, a opinião pública impediria que o poder se autonomizasse dos cidadãos e se convertesse em um poder autárquico.

A segunda função de uma opinião pública livre e robusta era positiva, na medida em que ela contribuía para o 220 deciframento da vontade da nação, tornando inteligível o interesse público. Como um instrumento de vocalização da vontade da nação, ela não se confundia com a expressão majoritária e numérica do voto, pois se constituía em um campo dialógico, regido pela razão, pela verdade, e não pela força da maioria. O bom funcionamento da representação eletiva dependia desse espaço público autônomo, no qual os cidadãos exerceriam uma participação política indireta porém permanente -, vigiando, pautando e direcionando o governo no sentido da vontade da nação.

\section{Supremacia constitucional}

No que diz respeito à formatação institucional da democracia no pensamento político de Rui Barbosa, merece especial atenção a centralidade atribuída por ele ao Poder Judiciário, em particular ao Superior Tribunal Federal. Em sua obra tardia, a democracia se definia mesmo como a expressão do governo da lei e, mais especificamente, um regime 
baseado na supremacia da Constituição. Nesse sentido, Rui criticava as doutrinas democráticas legicêntricas, isto é, que conferiam ao Poder Legislativo a summa potestas do regime. Recorrendo a autores clássicos como Thomas Jefferson, Alexander Hamilton, Alexis de Tocqueville, e a juristas contemporâneos seus, como o norte-americano Elihu Root (1845-1937) e o francês Émile Boutmy (1835-1906), Rui se empenhava em fundamentar teoricamente e legitimar o protagonismo do Poder Judiciário nas democracias modernas (Barbosa, 1989, [1914], pp. 242-44) ${ }^{11}$.

Para o jurista baiano, a democracia não se definia pela encarnação da soberania do povo em uma assembleia legislativa - que, para ele, poderia dar origem a uma "tirania das assembleias políticas" - mas, sobretudo, pela vigência do Estado de direito. O traço definidor das "democracias liberais", que Rui sonhava aplicar no Brasil, tinha precisamente no Poder Judiciário o seu eixo principal, daí sua admiração pela tradição anglo-saxã. Dirigindo-se a uma plateia de bacharéis, por ocasião de sua posse como presidente do Instituto dos Advogados em 1914, ele dizia que:

Nos governos despóticos, sob o Terror jacobino, com as ditaduras dos Bonapartes, debaixo das tiranias napolitanas, moscovitas ou asiáticas, a nossa profissão [a advocacia] ou não se conhece, ou vegeta como cardo entre ruínas. Na Grã-Bretanha, nos Estados Unidos, nas democracias liberais, na Austrália, na África Inglesa, nos países europeus ou americanos, que por esse tipo se modelarem, a toga, pela magistratura e pelo foro, é o elemento predominante. Dos tribunais e das corporações de advogados irradia ela

11 Para um contraponto com essa definição da democracia como supremacia da Constituição, ver a concepção autoritária de democracia desenvolvida mais tarde por Azevedo Amaral (1934, 1938, 1941) e Francisco Campos (1979 [1925], 1940), cujo eixo era precisamente a submissão do Poder Judiciário ao Executivo, concebido como encarnação da vontade una da nação (cf. Cintra, 2013, capítulo 6). 
a cultura jurídica, o senso jurídico, a orientação jurídica, princípio, exigência e garantia capital da ordem nos países livres (Barbosa, 1989 [1914], p. 225).

Rui concordava com a distinção feita pelo jurista norte-americano William B. Hornblower (1851-1914) entre o "governo do povo por todo o povo e para todo o povo" e o "governo absoluto de uma simples maioria do eleitorado em benefício exclusivo dessa maioria mesma" (Hornblower apud Barbosa, 1989 [1914], p. 248) ${ }^{12}$. Nessa formulação, o Poder Judiciário era concebido como representante do interesse nacional a longo prazo, como a nação em uma temporalidade lenta e uma salvaguarda da vontade geral contra o interesse imediato das maiorias ocasionais.

A Constituição de 1891, sustentava Rui, havia se inspirado precisamente nesse modelo - que, em alguns textos, ele denominou "democracia jurídica" -, cujo princípio basilar 222 era que os governos eleitos encontravam-se submetidos à supremacia constitucional (Barbosa, 1989 [1914], p. 231). $\mathrm{Na}$ forma presidencialista de governo, argumentava, a independência do Poder Judiciário e o controle de constitucionalidade adquiriam ainda maior relevância, pois atuavam como mecanismos para frear o poder político do presidente da República e das maiorias legislativas, evitando assim um "absolutismo tumultuário":

[...] o presidencialismo, por sua vez, não tendo, como não tem, os freios e contrapesos do governo parlamentar, viria a dar na mais tremenda forma do absolutismo, no absolutismo tumultuário e irresponsável das maiorias legislativas, das multidões anônimas e das máquinas eleitorais, se os direitos supremos do indivíduo e da sociedade, subtraídos pela ${ }^{12}$ Trata-se da obra The independence of the Judiciary, the safeguard of free institutions, de
Hornblower. 
Constituição ao alcance de agitações efêmeras, não tivessem na justiça o asilo de um santuário impenetrável (Barbosa, 1989-1914. p. 248).

A supremacia do Poder Judiciário, muito embora tivesse como paradigma a "cultura jurídica" de matriz anglo-saxã, em particular o modelo norte-americano, respondia a problemas específicos da organização política e social brasileira. Em nosso contexto particular - que, como vimos antes, era caracterizado por fraca organização e autonomia da sociedade civil, cooptação do parlamento e da imprensa pelo Executivo, em suma, em que a soberania nacional havia sido usurpada pelas oligarquias -, o Judiciário representava, para Rui, o último reduto no qual o interesse público e as liberdades civis ainda podiam ser observados. Como consequência, no Brasil o STF se arvorava na única instituição capaz de conter o poder oligárquico e contrapor-se "aos excessos do governo e aos das maiorias legislativas" (Barbosa, 1989 [1914], pp. 226-28).

É importante, portanto, salientar essa nuance na defesa da democracia jurídica de Rui e sua relação com o diagnóstico da situação brasileira. Enquanto nos Estados Unidos, a função dos tribunais consistia em moderar o ímpeto popular - nas palavras de Rui, impedir que a nação escorregasse no poço das "paixões populares", nas "aventuras revolucionárias", nos "imprevistos de uma democracia sem freios" (Barbosa, 1989 [1914], pp. 246-47) -, no Brasil seu papel tinha um sentido fundamentalmente antioligárquico. Em outras palavras, enquanto a Suprema Corte norte-americana muitas vezes contrariava as "maiorias populares", no Brasil o fortalecimento do STF não se daria no sentido de restringir os anseios imediatos da maioria, mas atuaria para limitar o predomínio das oligarquias encasteladas no poder (p. 181).

A esse respeito, vale ressaltar que a perspectiva situacionista sobre o papel do Judiciário no sistema político repu- 
blicano era diametralmente oposta à de Rui. O Comércio, jornal ligado ao Partido Republicano Conservador e ao grupo de Pinheiro Machado, por exemplo, expressava preocupação em relação ao fortalecimento institucional do Poder Judiciário e à possibilidade de que este viesse a contrariar os interesses do governo. Em 30 de setembro de 1914, um editorial desse jornal rechaçava da seguinte forma a intromissão do Judiciário nas disputas políticas:

Entre as espécies de ditadura que possam desgraçadamente ameaçar-nos nenhuma mais triste do que essa e nenhuma mais lastimável, porque seria a morte moral da nação, que assim nem mais as relações de sua vida civil seriam asseguradas, no dia em que o Judiciário esquecesse os seus deveres especiais e suas atribuições privativas para se intrometer no julgamento dos casos políticos ou se pronunciar sobre a organização dos corpos eletivos, únicos competentes para o deslinde das suas próprias dúvidas regimentais, como reguladores soberanos da sua própria economia interna (apud, Cavalcanti, 1983 [1914], p. 28).

No chamado "caso do Rio", em que a disputa eleitoral entre o Tenente Sodré e Nilo Peçanha ao cargo de presidente do Estado do Rio em 1914 acabou na Justiça, Pinheiro Machado era um dos que se empenhava em aplicar essa interpretação conservadora para levar a cabo uma intervenção federal em favor do Tenente Sodré ${ }^{13}$. Naquela ocasião, o "condestável da República" chamava de "facciosas as decisões do Supremo Tribunal Federal" (Nery, 1955, pp. 126-27) e sustentava que as controvérsias acerca das eleições e da

\footnotetext{
${ }^{13}$ Pinheiro Machado e seus aliados tentavam, pela verificação de poderes, empossar o Tenente Sodré, mas Nilo Peçanha garantiu sua posse por meio de um habeas corpus concedido pelo STF. O Presidente Wenceslau Braz, recém-empossado, contrariando o senador Pinheiro Machado, decidiu acatar a decisão do STF (Cavalcanti, 1983, pp. 27-34).
} 
verificação de poderes deveriam ser resolvidas não pelo Judiciário, mas pela "opinião dos legítimos órgãos da soberania nacional, que se têm manifestado, por meio das assembleias estaduais e dos presidentes de Estado" (Machado, 1981 [1915], p. 263). Segundo Pinheiro Machado (p. 266), ao garantir a posse de Nilo Peçanha por meio de habeas corpus, a Constituição tinha sido "violada por um poder, que exorbitou da sua competência, excedeu de suas atribuições, para intervir em questões de natureza política”.

Em confronto com essa interpretação "antijudicialização”, Rui defendia a competência do Poder Judiciário para decidir em última instância a validade dos diplomas legais, inclusive no que tange ao processo eleitoral e à verificação de poderes. Em sua interpretação maximizadora do habeas corpus, ele argumentava que tal instituto deveria ser aplicado não apenas nos casos em que o cidadão sofresse restrição da liberdade de locomoção ou "constrangimento corporal", mas em todos os casos em que houvesse "ilegalidade ou abuso de poder" (Barbosa, 1981 [1915], pp. 94-95).

Desse modo, Rui mobilizava a jurisprudência norte-americana sobre a aplicação do habeas corpus para demonstrar

[...] que a liberdade constitucional significa alguma cousa mais do que a simples liberdade ordinária; ela consiste nos direitos civis e políticos, que são absolutamente garantidos, assegurados e preservados; nas liberdades dos indivíduos como homens e cidadãos - nos seus direitos de voto e nos seus direitos de ocuparem os cargos que exercerem... (Barbosa, 1981, p. 96).

Nessa interpretação ampliada, o habeas corpus era um "esteio da ordem democrática" (Costa Filho, 1981, p. XIV), possibilitando ao cidadão gozar de seus direitos políticos de modo pleno. Não era limitado, portanto, o papel que Rui atribuía ao STF para a vigência das liberdades civis e públicas. 
No caso da decretação do Estado de sítio, não obstante reconhecer que a aplicação desse instituto dizia respeito ao caráter discricionário da política, Rui defendia que cabia em última instância ao STF julgar a validade do decreto presidencial, sobretudo para impedir o abuso daquele instituto. Nesse sentido, Rui afirmava que "se os atos de execução [do Estado de sítio] excederem a medida constitucional ou legal, legítima será e indenegável a interposição da justiça, já quanto à restituição do direito extorquido, já quanto à reparação do dano causado" (Barbosa, 1989 [1914], p. 191).

Alguns anos depois, no curso da campanha à presidência de 1919, o tema das liberdades civis e públicas e sua relação com a democracia voltava a ser objeto de apreciação de Rui. Em uma conferência pronunciada em abril daquele ano, intitulada $A$ corrupção política, ele insistia na legalidade dos atos públicos que possibilitassem ao povo 226 contestar os governos instituídos. O direito de criticar os governos, dizia ele, era

[...] comum a todos os cidadãos. Qualquer proletário, o mais humilde homem do povo poderia exercitar, no jornal ou na praça. Nem é um direito de limitações regionais. Todo o cidadão, em qualquer estado, o pode usar com relação a esse ou a qualquer outro e, combatendo a política dos estados, combater, com o mesmo desassombro de quem não sai do logradouro de sua individualidade legal, a política da União (Barbosa, 1956a [1919], p. 6).

Para Rui, direitos como o de expressão e reunião constituíam-se em pilares da democracia em todas as "nações livres”, e, para que fossem de fato efetivados, era necessário que o Poder Judiciário decidisse em última instância os atos dos governos que colocassem em risco tais direitos. Os tribunais se tornavam, assim, uma espécie de último dique 
contra os desmandos dos governos oligárquicos e a conversão da República brasileira em um regime autoritário (Barbosa, 1956a [1919], pp. 4-11).

Como se depreende do exame de sua atividade política e produção intelectual tardias, Rui Barbosa esteve engajado na crítica do status quo republicano. Para levar a cabo tal crítica, o autor muniu-se não apenas das armas teóricas fornecidas pelo liberalismo político - como o princípio da divisão dos poderes, o federalismo, a liberdade individual -, mas teve de investigar também as razões sócio-históricas da corrupção do regime republicano brasileiro. Nesse sentido, em seu diagnóstico de que o sistema político estava refém de oligarquias autointeressadas, que exerciam seu poder de maneira quase ditatorial, Rui não deixou de reconhecer certas debilidades ligadas à desorganização e subserviência da sociedade civil ao aparato político-administrativo. Ao contrário das acusações de seus adversários nacionalistas, o pensamento político de Rui Barbosa não foi simples importação e reprodução acrítica do liberalismo europeu em terra estranha. A recepção daquele repertório conceitual, em vez de representar um elemento de alienação cultural ou atestado de "idealismo utópico" do autor em relação às "singularidades nacionais", combinou-se com uma aguda consciência das dificuldades de sua implementação prática. É na tensão entre esse ideário liberal e a realidade brasileira refratária à sua acomodação que, a nosso ver, reside a interpretação mais profícua da obra de Rui Barbosa.

Como se buscou demonstrar aqui, o tema da democracia participa dessa tensão entre o normativo e o empírico. Para Rui, uma autêntica democracia liberal não poderia ser resumida à autorização eleitoral dos governantes. Para que pudesse ser expressa, a vontade da nação dependia de um espaço público relativamente autônomo em relação ao Estado 
e ao poder administrativo, o que para ele estava longe de ocorrer no Brasil. Ao contrário, aqui a vontade das urnas estava completamente dissociada da vontade da nação. A autorização eleitoral majoritária carecia de legitimidade porque os governos republicanos asfixiavam as instâncias que deveriam compor esse espaço público autônomo - parlamento, imprensa e associações civis.

Diante dessa situação, Rui passou a dar ênfase em dois eixos para a realização da democracia no Brasil. O primeiro deles seria o fortalecimento da sociedade civil, pela integração das classes trabalhadoras à vida política do país, inclusive reconhecendo a legitimidade de um conjunto de direitos sociais; a autonomia da opinião pública - notadamente a imprensa e a oposição parlamentar - também deveria ser garantida contra as tentativas de controle por parte do situacionismo. Já o segundo eixo dizia respeito à instituição de uma espécie de democracia jurídica, na qual o Poder Judi-

228 ciário, em particular o Superior Tribunal Federal, viesse a ocupar a posição de summa potestas do regime e guardião da Constituição, oferecendo resistência a decisões governamentais que pudessem violar direitos fundamentais. Só assim Rui Barbosa acreditava que se poderia escapar do círculo vicioso do domínio oligárquico-autoritário que vigorava no país com o nome de "República".

\section{Wendel Antunes Cintra}

é professor adjunto do Departamento de Ciência Política da Faculdade de Filosofia e Ciências Humanas da Universidade Federal da Bahia (UFBA).

\section{Bibliografia}

AMARAL, A. 1934. O Brasil na crise atual. Rio de Janeiro: Companhia

Editora Nacional. 1938. O Estado autoritário e a realidade nacional. Rio de Janeiro:

Livraria José Olympio Editora. 
1941. Getúlio Vargas, estadista. Rio de Janeiro: Irmãos Pongetti Editores.

ARAUJO, C. R. R. 2013. A forma da República: da constituição mista ao Estado. São Paulo: WMF.

ASSIS BRASIL, J. F. 1931 [1893]. Democracia representativa: do voto e do modo de votar. 4. ed. [ampl. e coment.]. Rio de Janeiro: s. ed. 1927. Dictadura, parlamentarismo, democracia. Rio de Janeiro: Livraria Editora Leite Ribeiro.

BARBOSA, R. 1989 [1914]. O Supremo Tribunal Federal na Constituição brasileira. Discurso proferido pelo Conselheiro Rui Barbosa no Instituto dos Advogados, ao tomar posse do cargo de presidente, em 19 de novembro de 1914. In: Trabalhos jurídicos. Rio de Janeiro: Fundação Casa de Rui Barbosa (Obras Completas de Rui Barbosa, v. 41 , t. IV). 1981 [1915]. Discursos parlamentares (1915). Rio de Janeiro:

Fundação Casa de Rui Barbosa (Obras Completas de Rui Barbosa, v. 42 , t. II). 1999 [1916]. Os conceitos modernos de direito internacional. In: Pensamento e Ação de Rui Barbosa. Organização e seleção de textos pela Fundação Casa de Rui Barbosa. Brasília: Editora do Senado Federal. 1986 [1919]. Às classes conservadoras. Conferência Pronunciada na

Associação Comercial do Rio de Janeiro, a 8 de março de 1919. Rio de Janeiro/São Paulo: Fundação Casa de Rui Barbosa/LTr. . 1998 [1919]. A questão social e política no Brasil. Rio de Janeiro:

Edições Casa de Rui Barbosa. . 1956a [1919]. A corrupção política. Conferência lida no

Teatro Politeama Bahia, a 12 de abril de 1919. In: . Campanha presidencial (1919). Rio de Janeiro: Fundação Casa de Rui Barbosa (Obras Completas de Rui Barbosa, v. 46, t. II). . 1956b [1919]. Manifesto de 17 de julho de 1919. In:

Campanha presidencial (1919). Rio de Janeiro: Fundação Casa de Rui Barbosa (Obras Completas de Rui Barbosa, v. 46, t. II). 1990 [1920]. A imprensa e o dever da verdade. 3. ed. São Paulo:

Editora da Universidade de São Paulo.

CAMPOS, F. 1979 [1925]. Francisco Campos: discursos parlamentares. Brasília: Câmara dos Deputados. 1940. O Estado Nacional: sua estructura, seu conteudo ideologico. Rio de Janeiro: Livraria José Olympio Editora.

CAVALCANTI, P. 1983 [1914]. A presidência Wenceslau Braz (1914-1918).

Brasília: Ed. Universidade de Brasília (Coleção Temas Brasileiros). 
CINTRA, W. A. 2013. Qual democracia? O governo do povo no pensamento político brasileiro. Tese de doutorado. Rio de Janeiro: Instituto de Estudos Sociais e Políticos, UERJ. 2014. Entre vanguarda e participação: a democracia no programa político da esquerda brasileira (1930-1935). Cadernos de Estudos Sociais, v. 29 , n. 2, pp. 38-65.

COSTA FILHO, O. 1981. Prefácio. In: BARBOSA, R. Discursos parlamentares (1915). Rio de Janeiro: Fundação Casa de Rui Barbosa (Obras Completas de Rui Barbosa, v. 42, t. II).

HOLLANDA, C. B. 2009. Modos da representação política: o experimento da Primeira República brasileira. Belo Horizonte/Rio de Janeiro: Ed. UFMG/IUPERJ.

LACOMBE, A. J. 1973. Prefácio. In: BARBOSA, R. Discursos parlamentares. Rio de Janeiro: Fundação Casa de Rui Barbosa. (Obras Completas de Rui Barbosa, v. 41, t. I).

LEAL, V. N. 1975 [1949]. Coronelismo, enxada e voto: o municipio e o regime representativo no Brasil. São Paulo: Alfa-Omega.

LOBATO, M. 2007 [1914]. Urupês. São Paulo: Globo.

LYNCH, C. E. C. 2012. O caminho para Washington passa por Buenos Aires: a recepção do conceito argentino de Estado de Sítio e seu papel na construção da República brasileira. Revista Brasileira de Ciências Sociais, v. 27, n. 78, pp. 149-96. 2014. Entre o liberalismo monárquico e o conservadorismo republicano: a democracia impossível de Rui Barbosa. In: . $D a$ monarquia à oligarquia: história institucional e pensamento político brasileiro (1822-1930). São Paulo: Alameda.

MACHADO, P. 1981 [1915]. Discurso do Senador Pinheiro Machado. Sessão em 20 de Janeiro de 1915. In: BARBOSA, R. Discursos parlamentares (1915). Rio de Janeiro: Fundação Casa de Rui Barbosa (Obras Completas de Rui Barbosa, v. 42, t. II).

MONTESQUIEU, Charles de Secondat, Baron de. 1996 [1748]. O espírito das leis. Tradução de Cristina Murachco. São Paulo: Martins Fontes.

MORAES FILHO, E. 1981. Prefácio. In: BARBOSA, R. Embaixada a Buenos Aires. Rio de Janeiro: Fundação Casa de Rui Barbosa (Obras Completas de Rui Barbosa, v. 43, t. I).

NERY, F. 1955. Rui Barbosa: ensaio biográfico. Rio de Janeiro: Casa de Rui Barbosa.

SILVA, C. 1982. Pinheiro Machado. Brasília: Ed. UnB (Coleção Temas Brasileiros). 
SKINNER, Q. 1996. As fundações do pensamento político moderno. Tradução de Renato Janine Ribeiro e Laura Teixeira Motta. São Paulo: Companhia das Letras.

TORRES, A. 1933 [1914]. O problema nacional brasileiro. São Paulo:

Companhia Editora Nacional. 1978 [1914]. Organização nacional. São Paulo: Editora Nacional.

VIANA FILHO, L. 1941. A vida de Rui Barbosa. São Paulo: Companhia Editora Nacional.

VIANNA, O. 1927. Idealismo da Constituição. Rio de Janeiro: Terra de Sol. 


\section{LIBERALISMO, JUSTIÇA E DEMOCRACIA: RUI BARBOSA E A CRÍTICA À PRIMEIRA REPÚBLICA BRASILEIRA (1910-1921)}

WENDEL ANTUNES CINTRA

Resumo: O artigo examina a obra tardia de Rui Barbosa e busca apreender o sentido de sua crítica à experiência republicana brasileira. A pesquisa se baseia fundamentalmente em textos, discursos e conferências publicadas e/ ou pronunciadas por Rui entre 1910 e 1921 e sustenta que o autor mobilizou um conceito normativo de democracia como alicerce de sua crítica ao status quo republicano. Tal conceito se fundamentava em dois pilares: (1) autonomia da sociedade civil, entendida como a organização das associações civis independentes e a formação de uma esfera pública livre de interferências governamentais, e (2) a primazia do Poder Judiciário, que se constituiria em summa potestas do regime republicano e teria a função de coibir abusos do Poder Executivo e das maiorias parlamentares.

Palavras-chave: Rui Barbosa; Primeira República; Democracia; Teoria Política Brasileira.

\section{LIBERALISIM, JUSTICE, AND DEMOCRACY: RUI BARBOSA AND HIS CRITICISM ABOUT THE FIRST BRAZILIAN REPUBLIC (1910-1921)}

Abstract: This article examines Rui Barbosa's late work and seeks to understand the meaning of his criticism about the Brazilian republican experience. The research is mainly based on Rui's texts, published and/or spoken speeches and conferences between 1910 and 1921, and it argues that the author has mobilized a normative concept of democracy as the foundation of his criticism about the Republican status quo. This concept was based on two pillars: (1) autonomy of the civil society, which was understood as the organization of independent civil associations and the 
establishment of a public sphere free of government interference; and (2) the primacy of the Judiciary Power, which would be the summa potestas of the Republican regime and would have the task of repressing abuses from the Executive and parliamentary majorities.

Keywords: Rui Barbosa; Brazilian First Republic; Democracy; Brazilian Political Theory.

Recebido: 16/06/2015 Aprovado: 07/10/2016 